\title{
Developing teaching material for descriptive writing subject by using think pair share model in elementary school
}

\author{
Farida Ariani ${ }^{1}$, Reflianto ${ }^{2}$, Nora Afnita ${ }^{3}$ \\ ${ }_{1}^{1}$ SD Kartika Jaya 1-11 Padang, Padang, Indonesia, arianifarida148@gmail.com \\ ${ }_{2}^{2}$ Universitas Negeri Malang, Malang, Indonesia, refliantomuslim@gmail.com \\ ${ }^{3}$ STIT Syekh Burhanuddin Pariaman, Pariaman, Indonesia, noraafnita12@gmail.com
}

\begin{abstract}
The aim of this research was to develop a teaching material of descriptive writing by using cooperative teaching model with think-pair-share type based on its validity, practicality and effectiveness. Three items of the analysis covered a content feasibility analysis, language analysis and layout analysis. The method of this study was research and development approach with Defining, Designing, Developing, and Disseminating (4-D) model. Instrument of this research used the observation sheets, field notes, questionnaire, interview form and focus group discussion. The result of research showed that developing teaching material for descriptive writing lesson by using think pair share model can be a good product. This teaching material product has been valid and feasible and has been passed the content analysis, language analysis, layout analysis and practical by experts'judgment and empirical studies. After doing some trial of this product can be concluded that the product was more effective to improve students' descriptive writing skill and can be more practical for Indonesian Language teachers of elementary school to use that. This product was expected become a prefer choice by teachers in the implementation of descriptive writing lesson for the fourth grade students of elementary school level.
\end{abstract}

Keywords: Teaching material, descriptive writing, think pair share

This is an open access article distributed under the Creative Commons 4.0 Attribution License, which permits unrestricted use, distribution, and reproduction in any medium, provided the original work is properly cited. (C2018 by author and Faculty of education, Universitas Negeri Padang.

\section{Introduction}

The learning process of writing skills of learners will be directed through the writing stages. Types of writing skills that must be mastered by elementary school one of them is descriptive writing skills. According to Indonesian Dictionary, description is the exposure or describing clearly about something in detail. Furthermore Rofi'uddin, et al (2011)argues that the description is an essay that describes the shape of an object (such as people, objects, places, events and so on) with the words The result of preliminary study on March 18, 2016 at fourth grade students of SDN 08 Beringin of Koto Tangah District, showed there were some problems in teaching descriptive writing: First, learners less led to determine the article topic to be made. Second, learners have weakness in making the writing outline. Third, when will begin to write, learners are confused how to begin the descriptive writing. Fourth, learners have some difficulty to develop their idea. It makes them difficult to arrange the descriptive writing task and have the repetition words. Fifth, in the publication stage the learners rarely to publish his works. 
These conditions make students' skill in the field of descriptive writing skill relatively low and do not use the correct writing stages. Learners do not specify a title of descriptive essay. In the second paragraph, descriptive writing of learners is very short. It was caused by learners do not make the outline so that there are no guidelines in developing the outline. In the post-writing stage, learners do not make the process of revision and editing so there are many errors in spelling and punctuation in their works.

Problems in descriptive writing in the research according to Urrutia \& Medina Gutierrez (2011)are learners hard to develop their ideas. Lack of vocabulary and poor teaching methods make. Siburian \& Medan (2013)reported some other problems was faced by elementary students compose a descriptive writing are learners have difficulty in developing a descriptive paragraphs or text, the difficulty of corrected words selection, and ineffective teaching methods.

Problems were also found in preliminary studies are teacher used an undersigned teaching materials according to students' needs and characteristics. Teachers use only one supporting books. In the implementation of teaching writing of descriptive paragraph, teacher did not evaluate of students' works in each stage of writing exercises including correcting, editing, revising and publishing the articles. Moreover, in terms of design, teaching materials was used by teacher tend to be monotonous and less attractive for learners to write. Teaching materials also lack of color variations.

There are seven indicators that the author developed at Basic Competency (BC) 8.1 contained only $28.6 \%$. In addition, in some fourth grade of text books used by learner in the field, are also less of appropriately instructional materials for descriptive writing stages. It can be seen in the first book of BSE IS, BC. 8.1 It is only $28.6 \%$ for the indicator of the book. Second book just $42.8 \%$, third book just $42.86 \%$ and fourth book just $42.8 \%$ of existing indicators.

Analysis of the fourth books mentioned above it can be seen that there is still a lot of discrepancy between the contents of the books with the demands of basic competency. Teaching materials from these textbooks was still a shortage: 1) resource is not in accordance with the competencies defined and have not loaded the overall indicator, 2) the majority of teaching materials was used by learners today have not loaded the stages of the writing process, pre-writing, while writing and post writing, (3) teaching materials are also less attractive for learners to make a works. It makes the learning process becomes less effective.

Based on the explanation above as an educator need a development of teaching materials by using Think Pair Share model to improve fourth grade elementary school students in composing a good descriptive writing. Teaching materials that can assist the learners in composing the outline to develop and revise the writings of learners. The aim of this study was to develop a teaching material of descriptive writing by using cooperative teaching model with think-pair-share type based on its validity, practicality and effectiveness.

\section{Method}

The method of this study was research and development approach with mix method research (Creswell W John, 2014)with Defining, Designing, Developing, and Disseminating (4-D) design. Instrument of this research used the observation sheets, field notes, questionnaire, interview form and focus group discussion. Subjects of this study were fourth grade students of elementary schools of SDN 08 Beringin Koto Tangah Padang as much as 20 students. Instrument of this research used questionnaire, field notes, observation sheet, descriptive writing test for measuring students' writing skill and focus group discussion to make sure the validity and feasibility of the product and passed the content analysis, language analysis, layout analysis and practical analysis by experts judgment and empirical studies result. 
Development Model used in this study refers to the 4-D models, proposed byThiagarajan, S., Semmel, D. S., \& Semmel (2010) this model has four stages: define, design, develop and disseminate or well known as (4-D) model.

Defining Phase.Itaims to establish and define the requirements needed in development of teaching materials. This phase is done by analyzing the objectives within the limits of the subject matter are developed. There are three steps are performed at the definition stages are first Curriculum Analysis. This stage is conducted review of the curriculum for learning of Indonesian Language to fourth grade of elementary school level. This analysis is needed to study the scope of curriculum materials, learning objectives, determining an appropriate strategy, developinga good teaching materialby using think-pair-share model. Second, Based on the preliminary study was known that previous teaching materials used at the current elementary school have not covered a validity of Competency Standard (CS) and Basic Competency (BC). Current teaching material only have the content about how learners to write but did not have content how to guide students in the writing process including the step of pre writing, while writing, and post writing. Therefore, teaching materials need to be developed with the adjustment of standard CS and BC as well indicators are in line with descriptive writing skills. Third, Needs analysis. It aims to determine the basic problems that required in the development of teaching materials. The analysis was conducted on teaching materials by seeing two main aspects, namely the content of the text and design. The contents of the text is the precision and accuracy of the information presented in the text. While the design is a way to express and display materials that have a reading level of interest and motivate learners in the learning process to compose a descriptive writing. Fourth, Analysis of Learners. It is a review of the characteristics of learners that includes age and development level of the children thinking ability. This analysis was conducted to get an idea of the characteristics of learners that will affect the electoral process and design development wasdone to match the development level of the learners. It is in accordance with the opinion of (Uno, 2007)that identify the behavior and characteristics of learners are very necessary to know the individual quality that can useit as an effect teaching materials of descriptive writing by using Think Pair Share model.

Designing Phase.At this stage the researchers is drafting the development of teaching materials including,1) the suitability of teaching materials based on the lesson plans development principles, 2) appropriateness analysis of teaching materials based on the competency standard and basic competency which refers to the components of teaching materials 3) suitability of teaching materials covered the writing process of pre writing, while writing, and post-writing and 4) suitability of presentation by using Think Pair Share model.

Developing Phase. The purpose of this stage is to produce a valid teaching materials, and practical. The development phase consists are first, Validity of Teaching Materials. It is done to determine whether or not a product function based on content, language. The main part is the conformity of BCvalidated, indicators, the truth of the concepts and the language used. Second, Enforceability of Instructional Materials. This stage aims to determine the practicalities of teaching materials. The practicalities are the utility level of teaching materials by students and teachers, which is carrying out trials of learning by using teaching materials that have been revised based on ratings validator. Then to determine the practicalities of teaching descriptive writing materials requested by teacher and learner by using a model of think pair share. The observations were made by two observers, namely teachers and researchers. Observer will observe the enforceability of teaching materials in the learning process and fill the observation instruments that have been prepared. Furthermore, the observer completed the utility questionnaires of descriptive writing skills materials by using Think Pair Share model

Disseminating Phase.It is the final stage of 4-D model. Once validated and tested the practicalities of model, the obtained materials of descriptive writing skills should be pass the validity and practicality test through the evaluation of teaching process by using Think Pair Share model. After 
that, in the disseminating stage, researcher did the trials the product to the schoolsofSDN 08 and SDN 06 Baringin. It aims to look at the effectiveness of the teaching materials developed. To know the teaching materials developed run effectively or not it can be seen from the results of learners writing skill. It can be done by observing the students' activities and students' writing achievement after using the product with Think Pair Share model.

\section{Results and Discussion}

Preparation of the teaching materials for descriptive writing is designed by using think pair share model. This design used teaching materials that has been disseminated in advance and adapted to the characteristics of the learners' development. Teaching materials was developed from the results of the based competency analysis and indicators are formulated and prepared in accordance with the stages of writing.

In addition, the concept of teaching materials was developed by using more attractive colors in order to attract the learners' attention. In each of the tasks was given attractive display with some icons. It aims to make student focus for their learning according to the stages of writing by using think pair share model. Furthermore, the presentation of teaching materials in the form of printed product was typed with Times New Roman font 12. The design provided with a blue background, blue and yellow and for header and footer were red and yellow. A Teaching material was typed by using Microsoft Word 2007 and uses a various size of font. In addition, it also used the main icon is a boy was writing and some of the boys and girls dressed in red and white uniforms. Under these conditions, the teaching materials designed were more unpopular learners and can support the learning process.

The format of teaching materials development is modified from the structure of the subject according to Education Ministry Rule which consists of, cover, introduction, table of contents, instructions for use, Basic Competency to be achieved, title, objectives, tasks, supporting information, and bibliography. The development phase of this product includes the validation of teaching materials and product trials to look at the practicalities and effectiveness of the product developed. Testing the validity of product was done by experts and practitioners, then the product to be revised. Lesson plans and teaching materials was validated by 6 validator. The validity of teaching materials practicality that has been developed in the learning process in the classroom can be explained as follows:

Table1. Lesson Plan Revision and Teaching Material

\begin{tabular}{ll}
\hline \multicolumn{1}{c}{ Lesson Plan } & \multicolumn{1}{c}{ Teaching Material } \\
\hline Writing repaired in accordance validator's advice. & $\begin{array}{l}\text { The use of more appropriate sentence based on } \\
\text { advice from the validator. }\end{array}$ \\
\hline $\begin{array}{l}\text { Learners' responses of the product have been listed } \\
\text { according to the validators' advice. }\end{array}$ & $\begin{array}{l}\text { The misspellings of word have been removed } \\
\text { based on advice from the validator }\end{array}$ \\
\hline $\begin{array}{l}\text { The character values of learners have been listed in } \\
\text { accordance with the purpose of learning. }\end{array}$ & $\begin{array}{l}\text { Writing punctuation has been corrected based } \\
\text { on advice from the validator }\end{array}$ \\
\hline
\end{tabular}

After revising the teaching materials, it was returned to the validator. Validator asked to give an opinion on the assessment of teaching materials that have been designed. The Validation otherwise has been completed if the validator has stated that the teaching materials are valid and ready for application in the field.

Lesson Plan validation was conducted on several aspects, including the identity, formulating the learning goals, the selection of teaching materials, methods and measures of learning, the 
selection of learning resources and assessment. The validation results of the lesson plan from all validator can be seen in the following table:

Table 2. Validation of Lesson Plan

\begin{tabular}{|c|c|c|c|c|c|c|c|c|c|}
\hline \multirow{2}{*}{ No } & \multirow{2}{*}{ Items } & \multicolumn{6}{|c|}{ Score of Validator } & \multirow{2}{*}{ Amount } & \multirow{2}{*}{ Valid Value } \\
\hline & & V1 & V2 & V3 & V4 & V5 & V6 & & \\
\hline 1 & Aspects of identity & 7 & 7 & 7 & 7 & 7 & 7 & 42 & $87.5 \%$ \\
\hline 2 & $\begin{array}{l}\begin{array}{l}\text { Formulation of learning } \\
\text { objectives }\end{array} \\
\end{array}$ & 11 & 11 & 11 & 11 & 11 & 11 & 66 & $91.6 \%$ \\
\hline 3 & $\begin{array}{l}\text { Selection of learning } \\
\text { materials }\end{array}$ & 7 & 7 & 7 & 7 & 8 & 7 & 43 & $89.6 \%$ \\
\hline 4 & Method and learning steps & 17 & 19 & 19 & 18 & 19 & 19 & 111 & $92.5 \%$ \\
\hline 5 & $\begin{array}{l}\text { Selection of learning } \\
\text { resources }\end{array}$ & 13 & 15 & 15 & 15 & 15 & 15 & 88 & $91.6 \%$ \\
\hline 6 & aspects of assessment & 7 & 8 & 7 & 7 & 8 & 8 & 45 & $93.7 \%$ \\
\hline & Total & & & & & & & & 546.5 \\
\hline & Average & & & & & & & & $91 \%$ \\
\hline
\end{tabular}

Based on the table 2 above can be explained that the average score on the identity aspect was $87.5 \%$ in the category of most valid. The average validity of formulation aspects of learning objectives in the lesson plan was $88.8 \%$. It was also most valid category. The average validity of selections of learning materials in the lesson plan was $91.6 \%$ and come into most valid category. The average validity of preparation aspects of learning resources was $89.6 \%$ also come into most valid category. The average validity of the assessment aspects was $91.6 \%$, it was also most valid. All validation of the lesson plan was conducted by experts and practitioners of validator totally $91 \%$ with category of most valid. Conclusions from the analysis to overall lesson plan for improving fourth grade students' descriptive writing skills by using think pair share model.

Validation of subject was done by considering some aspects covered feasibility, content, language, and lay out. Results of the validation of data processing on teaching material can be seen in the following table:

Table 3. Validation of Subjects

\begin{tabular}{|c|c|c|c|c|c|c|c|c|c|}
\hline \multirow{2}{*}{ No } & \multirow{2}{*}{ Items } & \multicolumn{6}{|c|}{ Score of Validator } & \multirow{2}{*}{ Amount } & \multirow{2}{*}{$\begin{array}{c}\text { Validity } \\
\text { Value }\end{array}$} \\
\hline & & V1 & V2 & V3 & V4 & V5 & V6 & & \\
\hline 1 & Contents & 22 & 22 & 23 & 22 & 23 & 23 & 135 & 93.7 \\
\hline 2 & Linguistic & 14 & 15 & 15 & 14 & 14 & 15 & 87 & 90.6 \\
\hline \multirow[t]{3}{*}{3} & Lay out & 13 & 14 & 14 & 14 & 15 & 15 & 85 & 88.5 \\
\hline & Total & & & & & & & & 272.8 \\
\hline & Average & & & & & & & & 90.9 \\
\hline
\end{tabular}

Based on the table 3 above can be explained that the average of validity of subject material covered the feasibility aspect of content was $93.7 \%$, it means that the whole content of teaching materials have been matched with the specified contents. The average of language validity was $90.6 \%$. It means that the language used in teaching materials have been matched with the rules of Indonesian language, effective and efficient. The average of lay out validity and picture aspect was $88.5 \%$, it indicates that teaching materials of writing have been designed by attractive appearance. Overall 
scores on the validation of teaching materials were done by experts and practitioners with total $90.9 \%$ and come into the most valid category.

Practicality of Lesson Plan was evaluated by focusing to assess whether the design have been fulfilled the criteria of well-designed and seeing the possibility of being some obstacles in the use of it. The practicality of lesson plan was evaluated by using the observation sheets. It was used tomeasure the enforceability of existing lesson plan. The Practicality Results of lesson plan can be seen in the following table:

Table 4. Practicality of Lesson Plan

\begin{tabular}{|c|c|c|c|c|}
\hline \multirow[t]{2}{*}{ Meeting } & \multicolumn{2}{|c|}{$\begin{array}{c}\text { Percentage of Vote } \\
\text { Observers }\end{array}$} & \multirow[t]{2}{*}{ Frequency } & \multirow[t]{2}{*}{ Category } \\
\hline & P1 & P2 & & \\
\hline First & $87.0 \%$ & $92.2 \%$ & $89.6 \%$ & very practical \\
\hline Second & $91.3 \%$ & $89.6 \%$ & $90.45 \%$ & very practical \\
\hline \multirow[t]{2}{*}{ Third } & $88.7 \%$ & $94.8 \%$ & $91.7 \%$ & very practical \\
\hline & & Average & $90.5 \%$ & very practical \\
\hline
\end{tabular}

Based on the table 4 above showed that the practicality percentage of lesson plan was $89.6 \%$. In the second meeting got the percentage of next Lesson Plan was $90.45 \%$. And in the third meeting was $91.7 \%$. The practicality of lesson plan for teaching material of descriptive writing by using think pair share model obtained from $89.6 \%$ to $91.7 \%$. The average value of the lesson plan practicality was $90.5 \%$ came into very practical category.

The practicality of teaching materials for the lesson of descriptive writing text by using think pair share model was evaluated from teachers' responses of the product when they used it in the teaching and learning process in the classroom. Result of teachers' responses can be seen in Table 5 below. 
Table 5. Teachers' Responses of Product Practicality

\begin{tabular}{|c|c|c|c|}
\hline \multirow[t]{3}{*}{ No } & \multirow[t]{2}{*}{ Items } & \multicolumn{2}{|c|}{ Score } \\
\hline & & T1 & $\mathrm{T} 2$ \\
\hline & Practicality in Use & & \\
\hline 1 & $\begin{array}{l}\text { Teaching materials allows teachers to teach the material on the } \\
\text { learner }\end{array}$ & 4 & 4 \\
\hline 2 & $\begin{array}{l}\text { Instructions on teaching materials allows teachers to convey the } \\
\text { intent and purpose of various activities to learners }\end{array}$ & 3 & 4 \\
\hline 3 & $\begin{array}{l}\text { Teaching materials allows teachers to interest students in learning } \\
\text { The Timeliness }\end{array}$ & 4 & 3 \\
\hline 4 & Steps in the appropriate allocation time for Lesson Plan & 4 & 4 \\
\hline 5 & $\begin{array}{l}\text { The use of teaching materials in accordance with the allocation } \\
\text { provided } \\
\text { Suitable Illustration }\end{array}$ & 4 & 3 \\
\hline 6 & $\begin{array}{l}\text { Images in teaching materials allows teachers to help students } \\
\text { understand the subject }\end{array}$ & 3 & 4 \\
\hline 7 & $\begin{array}{l}\text { Placement of appropriate illustrations to make student easier to } \\
\text { understand } \\
\text { Language }\end{array}$ & 4 & 3 \\
\hline 8 & The language used in the syllabus refer to corrected EYD & 4 & 4 \\
\hline 9 & The language used in the Lesson Plan in refer to corrected EYD & 4 & 4 \\
\hline 10 & The language used in teaching materials refer to corrected EYD & 4 & 4 \\
\hline 11 & Presentation of the sentence was easily understood by teachers & 3 & 3 \\
\hline & Total scores obtained & 41 & 40 \\
\hline & Percentage of practicality & $93.1 \%$ & $90.9 \%$ \\
\hline & Average of practicality Percentage & & \\
\hline & Category & very & tical \\
\hline
\end{tabular}

Based on the table 5 above showed that the result of teachers' response after using the teaching material of descriptive writing subject to fourth grade elementary student at SD Negeri 04 Baringin Koto Tangah for four aspects assessed covered practicality, timeliness, suitability illustrations and language obtained the average of teacher response to the teaching materials was $92 \%$ came into very good category. It means that the teaching material developed by the researchers was very helpful for teacher to teach the descriptive writing subject by using think pair share model. These materials are considered as new innovations in the learning process, especially in the world of education.

After evaluating teachers' responses of the product, and then do the evaluation of students' response about the practicality of teaching material product in studying the descriptive writing with guidance of the teaching materials developed by using think pair share model. This assessment is carried out by 30 learners at the end of trial. Analysis of data obtained any assessment response of learners against the practicality of teaching materials. Shortly to measure the practicality of teaching materials for learners can be seen in the following table. 
Table 6. Students' Responses of Product Practicality

\begin{tabular}{clcc}
\hline No & \multicolumn{1}{c}{ Items } & \multicolumn{1}{c}{ Category } \\
\hline 1 & I like the look of teaching materials as it draws my attention & $88.3 \%$ & Very Practical \\
\hline 2 & $\begin{array}{l}\text { Teaching materials have an interesting color and makes me } \\
\text { happy to learn that. }\end{array}$ & $89.1 \%$ & Very Practical \\
\hline 3 & $\begin{array}{l}\text { Learning subject on teaching materials have relevance to my } \\
\text { everyday life }\end{array}$ & $90.0 \%$ & Very Practical \\
\hline 4 & $\begin{array}{l}\text { I'm easy to understand the instructions by using this } \\
\text { teaching material. }\end{array}$ & $87.5 \%$ & Very Practical \\
\hline 5 & $\begin{array}{l}\text { Images used in teaching materials helped me to easier } \\
\text { understand the concept well }\end{array}$ & $85.8 \%$ & Very Practical \\
\hline 6 & $\begin{array}{l}\text { I'm active to participate in the use of teaching materials that } \\
\text { make my motivation to study increase }\end{array}$ & $83.3 \%$ & Very Practical \\
\hline 7 & $\begin{array}{l}\text { Subject in the teaching materials help me to easily } \\
\text { understand the material was being taught }\end{array}$ & $85.0 \%$ & Very Practical \\
\hline 8 & $\begin{array}{l}\text { Pictures on teaching materials helps me to clarify the subject } \\
\text { matter well }\end{array}$ & $82.5 \%$ & Very Practical \\
\hline 9 & $\begin{array}{l}\text { The activities stages of descriptive writing by using this } \\
\text { productreally help me to understand how to write a } \\
\text { descriptive composition }\end{array}$ & $90.0 \%$ & Very Practical \\
\hline 10 & $\begin{array}{l}\text { The use of teaching materials in accordance with the } \\
\text { allocation time available really helped me in doing the } \\
\text { exercises given. }\end{array}$ & $90.8 \%$ & Very Practical \\
\hline 11 & $\begin{array}{l}\text { Activity sheets in the teaching material helped me } \\
\text { understanding the stages of writing a descriptive text }\end{array}$ & Average & $\mathbf{8 7 . 2 \%}$ \\
\hline
\end{tabular}

Based on the table 6 explanted above can be concluded that the analysis of fourth grade students' response at SD Negeri 04 Baringin that has been taught by using teaching material with think pair share model to understand about how to compose a descriptive paragraph obtained their response covered to eleventh aspects. The higher response of students was in the first aspect, $88.3 \%$ came into very practical category. Second aspect was $89.1 \%$, third aspect was $90 \%$ fourth was is $87.5 \%$, fifth aspect was $85.8 \%$ sixth aspect was $83.3 \%$, seventh aspect was $85 \%$ eighth aspect was $82.5 \%$, ninth aspect was $90 \%$., tenth aspect was $90.8 \%$ and eleventh aspect was $92.5 \%$. All aspects came into the very practical category.

The average of practicality percentage of all learners' response was $87.2 \%$, it is also very practical. It means that, using teaching material provided by using a Think Pair Share model to teach how to write a descriptive paragraph can motivate students and improve their skill in composing a descriptive essay well. 


\section{Effectiveness of Teaching Material}

Learners' activities was observed by using instruments covered 1) Visual Activities (VA), are watching and listening to the teacher explanation, 2) Listening Activities (LA), which is listening to the teacher's explanations, 3) Motor Activities (MA), measuring the teaching materials, 4) Oral Activities (OA), asking and questions stages, and 5) Writing Activities (WA), which is doing the exercises of writing a descriptive essay by using teaching materials designed. For more details can be seen in the following table.

Table 7. Effectiveness of Students' Activities

\begin{tabular}{|c|c|c|c|c|c|c|c|c|}
\hline \multirow{2}{*}{ No } & \multirow{2}{*}{ Meeting } & \multicolumn{6}{|c|}{ Students. Activities } & \multirow[t]{2}{*}{ Category } \\
\hline & & VA & LA & MA & $\mathrm{OA}$ & WA & Average & \\
\hline 1 & First Meeting & 83.3 & 81.6 & 85 & 83.3 & 81.6 & 82.9 & Excellent \\
\hline 2 & Second Meeting & 86.6 & 86.6 & 86.6 & 86.6 & 85 & 86.2 & Excellent \\
\hline \multirow[t]{2}{*}{3} & Third Meeting & 88.3 & 88.3 & 91.6 & 91.6 & 85 & 88.9 & Excellent \\
\hline & Average & & & & & & $86 \%$ & Excellent \\
\hline
\end{tabular}

Based on the table 7 above can be explained that the activity of student in the first meeting was $82.9 \%$, second meeting was $86.2 \%$ and third meeting was $88.9 \%$. The overall average of students'activities obtained an average score of $86 \%$. All level was in the excellent category. It means that by using this product can be stimulate the students' enthusiastic when following the teachinglearning process by using teaching materials developed with think pair share model.

The effectiveness of product viewed from student writing skill can be evaluated from their descriptive writing achievement trough descriptive writing testing. After collecting the data of students' writing achievement of descriptive by using the assessment rubric of writing skills obtained the data of their achievement as follows:

Table 8. Assessment Process of Students' Descriptive Writing Skill

\begin{tabular}{|c|c|c|c|c|c|c|}
\hline \multirow{2}{*}{ No } & \multirow{2}{*}{ Indicator } & \multicolumn{3}{|c|}{ Grade Value (\%) } & \multirow{2}{*}{ Average } & \multirow{2}{*}{ Category } \\
\hline & & M1 & M2 & M3 & & \\
\hline & Pre Writing & & & & & \\
\hline 1 & Deciding on a theme & 98.5 & 98.9 & 98.9 & 98.7 & Very high \\
\hline 2 & Determining title & 95.6 & 97.8 & 96.7 & 96.7 & Very high \\
\hline \multirow[t]{2}{*}{3} & Creating a framework & 83.3 & 86.7 & 91.1 & 87.0 & Very high \\
\hline & While Writing & & & & & \\
\hline \multirow[t]{2}{*}{4} & $\begin{array}{l}\text { Develop a framework for } \\
\text { writing }\end{array}$ & 86.7 & 88.9 & 91.1 & 88.9 & Very high \\
\hline & Post Writing & & & & & \\
\hline 5 & Revising the writings & 95.6 & 95.6 & 97.8 & 96.3 & Very high \\
\hline \multirow[t]{2}{*}{6} & Edit the article & 75.6 & 77.8 & 78.9 & 77.4 & High \\
\hline & Average & 89.3 & 90.9 & 92.4 & 90.8 & Very high \\
\hline
\end{tabular}

Based on table 8 above showed the results of assessment process on descriptive writing skills by using think pair share model on pre-writing stage are in the range of $87 \%$ to $98.7 \%$. It was in the very 
high category. It means that learners are able to determine the theme, title and make the outline well. At the current stage of while writing obtained $88.9 \%$ with a very high category. It means that students enabled to develop the outline. In the final stage of post writing the value started from $77.4 \%$ to $96.3 \%$ with a very high category. It means that learners enabled to revise, edit, and publish the results of his/her essay in front of the class with an excellent skill. The average ratings of overall descriptive writing skill of students was $90.8 \%$ came into a very high category. It means that the learning progresses of learners was able to compose a good descriptive writing process based on their excellent understanding by guiding with teaching materials developed. The achievement of students' writing in composing a descriptive essay can be accounted by using likert scale 5 point for five items of descriptive text. The data of students' achievement in composing a descriptive essay as follows:

Table 9. Students' Achievementin Composing a Descriptive Essay

\begin{tabular}{clccccc}
\hline No & \multicolumn{1}{c}{ Indicator } & PBI $(\%)$ & PB2 $(\%)$ & PB3 $(\%)$ & Average & Category \\
\hline 1 & Quality of content, & 90.8 & 94.0 & 95.8 & 93.5 & Very high \\
\hline 2 & $\begin{array}{l}\text { Accuracy and breadth of } \\
\text { content, }\end{array}$ & 82.5 & 90.0 & 93.3 & 93.3 & Very high \\
\hline 3 & Writing organization, & 84.2 & 84.2 & 90.0 & 90.0 & Very high \\
\hline 4 & Precision of diction, & 80.0 & 81.7 & 83.3 & 83.3 & Very high \\
\hline 5 & Accuracy of the sentence, & 81.7 & 82.5 & 85.8 & 85.8 & Very high \\
\hline 6 & Spelling and Grammar & 80.8 & 82.5 & 84.2 & 84.2 & Very high \\
\hline & Average & $\mathbf{8 3 . 3}$ & $\mathbf{8 5 . 8}$ & $\mathbf{8 8 . 8}$ & $\mathbf{8 6 . 0}$ & Very high \\
\hline
\end{tabular}

Based on the table 10 can be explained that the average of students' achievement in composing a descriptive essay based on six indicator such as quality of content of $93,5 \%$, accuracy and breadth of the content was $93.3 \%$, writing organization was $90.0 \%$, accuracy of diction was $85.8 \%$, accuracy spelling and Grammar was 84.2. All indicators of descriptive writing assessment come into a very high category. Range of values for each indicator was from $80.0 \%$ to $95.8 \%$ which belong to the very high category. The average value of students' descriptive writing skills was 86.0 with a very high category. It can be concluded that the students' writing descriptive skills can be more effective if using this teaching material product.

The results of data validation on the lesson plan was examined by the expert was $90.3 \%$ and $92.1 \%$. Based on predefined categories, the lesson plan has been developed into the excellent category. It also has been developed by describing the suitability of the whole component, activities and concepts that had been contained therein. Conformity is evident from the indicators and learning objectives had been formulated, the material selected, steps cooperative models by using think pair share model, learning steps, media and learning resources, as well as assessment. That was, in general had been able to describe the lesson plan component in accordance with the Ministerial Regulation No. 41 of 2007.

Development of teaching materials by applying think pair share method is intended to strengthen the students' inspiration while they are following the learning of descriptive writing in the classroom, including developing the power of design, content; language, lay out, and the practicality of module and convenience of it in the use for teachers and students in the classroom. Development of teaching material that we have done including curriculum design; teaching methods, and build a conducive teaching environment. These characteristics are consistent with Chen, Brown, Hattie, \& Millward (2012)Reported that in the development of teaching materials need to consider the advantages of literature used 
including the characteristics of the design, content; language, lay out, and practicality of teaching material in use.

Development of teaching materials which is combined by teaching methods of think pair share is to encourage teachers to be more inspiration in providing a good teaching materials for her students with clearly stages and related to the topics taught and pay attention to quality of teaching material developed (Hennessy et al., 2014). In this way is expected to increase the excitement of students in the classroom to follow the teaching and learning process.

Developing an inspiring teaching material for classroom teaching is not only for teachers and students but also to encourage students' interest to repeat the lessons with pleasure. The climate of developing the teaching materials in the strengthening of students' interest is increasingly important in order to get the expected learning competencies, of course, by taking into account the various social changes in learning (Skelton, 2016, P. 257). For elementary school teacher, the development of teaching material are teachers' tasks and responsibility to build the quality of learning for her students to be more interesting and not boring, by designing an attractive teaching materials and inspiring.

Challenges in developing the teaching materials were inspired by involving the think pair share method of teaching. It can be done by paying attention to the theme or topic of appropriately teaching materials and easily for students to understand: the ease students acquire information in a clear and have interesting lay out that encourages them love to learn the topic by using guidelines available in the teaching material developed. The results of this study in terms of design, content, language, lay out including the selection of the evaluation is very valid and proven to increase the ability of students' descriptive writing at the level of elementary school in the fourth graders at SDN 08 Baringin Padang. This study is consistent with the results of Cotterill (2015) who developed a complex models and inspiring teaching material by paying attention of validity and practicality of using it. In terms of validity, he also measured in terms of instructional design appearance, content, language, layout and evaluation of the materials selection. The development of teaching materials also contain a variety of information, interesting and challenging highlighted as a key factor for an individual to consider the attractiveness of teaching materials for students, in addition to pay attention to the practicality of the use it in the school environment as much as possible. In fact it can encourage student interest to learn itself although away from his or her teachers' supervision. Design of teaching materials was developed reference to the curriculum needs and it is very important to observe in a study of the development of excellent teaching material component (Kreber \& Cranton, 2000).

In the theme of improving students' creative thinking ability in the line with of descriptive writing, teachers need to develop teaching materials that are able to build a students' creative mindset, not only need creative thinking among students and teachers, but also creative thinking among students and other students in form of cooperative learning by using think pair share method. The results of this study proven that the teaching materials was developed is really practical and fit for use by Indonesian teachers to fourth grade student at the elementary school level in teaching the topic of writing descriptive. Teaching materials are not only creative but also enable to stimulate students' critical thinking capabilities, as well as students' ability to choose the right words in the drafting of paragraph and writing systematic in compose a descriptive writing. By this way, students wereexpected to be readable and easily understood about his or her task. It 
can be achieved by taking into account some internal and external factors when considering teaching materials developed, such as the interests of students, classroom conditions, the attractiveness of the topic and teaching method used by teachers. Consideration of external factors is consistent with research was conducted by Hetherington \& Wegerif (2018)That external factors such as the media, classroom conditions and teaching methods is crucial for the success of students; learning in the classroom, including teaching Indonesian language with the topics of descriptive writing.

\section{Conclusions}

Based on finding and discussion above can be concluded that the development of teaching module for a descriptive writing subject by using think pair share model to the fourth grade students of elementary school of SDN 8 Baringin Padang had given some important information about the effectiveness of teachers and students in following the teaching learning process of descriptive writing study in the class by think pair share models. The product of module had been valid and feasible in the line of content, language, layout, and its practicality. This module can also be more effective to improve fourth grade students' descriptive writing skills.

\section{Acknowledgments}

We thanks so much to our colleagues of Joni Indra Wandi, M.Pdwho provided insight and expertise that greatly contribution to the research analysis. We also thanks a lot to Zelhendri Zen, M.Pd who help us in the particular technique, methodology and comments for greatly improvement of this paper.

\section{References}

Chen, J., Brown, G. T. L., Hattie, J. A. C., \& Millward, P. (2012). Teachers' conceptions of excellent teaching and its relationships to self-reported teaching practices. Teaching and Teacher Education, 28(7), 936-947. https://doi.org/10.1016/j.tate.2012.04.006

Cotterill, S. T. (2015). Inspiring and motivating learners in Higher Education: The staff perspective. Journal of Hospitality, Leisure, Sport and Tourism Education, 17, 5-13. https://doi.org/10.1016 /j.jhlste.2015.07.003

Creswell W John. (2014). Research Design, Qualitative, Quantitative and Mixed Methods Approaches (4th ed.). SAGE Publication, Inc.

Hennessy, C., Adams, G., Mahon, E., Nixon, S., Pratt, A., \& Williams, L. (2014). Discovering inspiring teaching: immersive models of staff development. Quality Assurance in Education, 22(3), 240-254. https://doi.org/10.1108/QAE-01-2013-0006

Hetherington, L., \& Wegerif, R. (2018). Developing a material-dialogic approach to pedagogy to guide science teacher education. Journal of Education for Teaching, 44(1), 27-43. https://doi.org/10.1080/ 02607476.2018.1422611

Kreber, C., \& Cranton, P. A. (2000). Exploring the scholarship of teaching. Journal of Higher Education, 71(4), 476-495. https://doi.org/10.2307/2649149

Rofi'uddin. (2011). Pendidikan Bahasadan Sastra Indonesia di KelasTinggi. Malang: Universitas Negeri Malang Pers.

Siburian, T. A., \& Medan, U. N. (2013). Improving Students ' Achievement on Writing Descriptive Text Through Think Pair, 3(July), 30-43.

Skelton, A. (2016). Teaching in Higher Education Value conflicts in higher education teaching, 
2517(January), 257-269. https://doi.org/10.1080/13562517.2011.611875

Thiagarajan, S., Semmel, D. S., \& Semmel, M. I. (2010). Instructional Development for Training Teachers of Exceptional Children: A Sourcebook. Center for Innovation in Teaching the Handicapped. Indiana: Indiana University Bloomington.

Uno, H. (2007). Perilaku dan Motivasi Pembelajaran. Jakarta: BumiAksara.

Urrutia, L. J., \& Medina Gutierrez, A. S. (2011). Adolescents' Awareness of Environmental Care: Experiences when Writing Short Descriptive Texts in English. Profile, 13(1), 11-30. Retrieved from http://search.proquest.com/docview/902094621?accountid $=14548 \% 5$ Cnhttp://metadata.lib. hku.hk/hku?url_ver=Z39.88-2004\&rft_val_fmt=info:ofi/fmt:kev:mtx:journal\&genre=article\&sid $=$ ProQ:ProQ:1lba\&atitle=Adolescents'+Awareness+of+Environmental+Care:+Experience 